\title{
Contemporary factors influencing association conference attendance
}

\begin{abstract}
Competition amongst conference tourism destinations has intensified. Understanding the factors influencing delegate attendance thus becomes increasingly important. This paper aims to extend the current body of academic knowledge by examining motivators and inhibitors deriving from not only previous academic research but also contemporary industry reports. Delegate expectations relating to new and established factors influencing conference attendance are explored, while motivating and inhibiting factors are ranked in order of importance. Proactive management and organisation responses to these factors are proposed. The research findings are important to destination managers in prioritising the investment of their limited resources aiming to address the higher-importance factors. This allows such destinations to improve in their competitiveness in attracting conference tourism and conference delegates.
\end{abstract}

Keywords: conference delegates; destinations; conference attendance; motivators; inhibitors 


\section{INTRODUCTION}

Benefits deriving from conference tourism have been frequently highlighted. Destinations have shown interest in conference tourism mostly due to the profit it generates through conference delegates' expenditure, which is approximately three times as much as that of leisure tourists (Campiranon \& Arcodia, 2007; Solly, 2012). Conference tourism has a positive economic impact due to the large number of delegates per conference who stay longer at a destination than leisure travellers and who frequently join pre- and post-conference tours (Kim, Chon \& Chung, 2003). Such wealth is broadly distributed amongst conference-complementing activities including accommodation, meals, souvenirs, retail outlets, parking fees, transportation fees, domestic airfares, and entertainment (Bernini, 2009, Grado, Strauss \& Lord, 1998; Horváth, 2011, Kim et al., 2003; Lee, Lee \& Yoon, 2013) and helps reduce seasonality issues as it is strong during off-peak leisure travel seasons (Ryan, Crotts \& Litvin, 2008). Furthermore, the conference industry has been identified as a prerequisite in the modern global market (Hanly, 2011), with constant increase in the number of meetings confirming such claims (Chatzigeorgiou, Christou \& Simeli, 2017).

As destinations acknowledge the increased benefits of conference tourism, competition to host conferences grows stronger, making this sector one of the most competitive within the tourism industry (Cró \& Martins, 2018; Hussain, Ragavan, Kumar \& Navye, 2014). This competition has intensified with the forecast increase in the number of conferences and decrease in attendees and budget per conference (Shapiro, 2011). Destinations and stakeholders therefore strive to identify what makes them more attractive than their competitors. Conference delegates are key players in this, as they act as end clients for conferences by deciding whether to attend a conference or not (Rogers, 2013). This paper focuses on the delegates' perspectives and 
aims to identify the important contemporary motivators and inhibitors for such attendance.

This study aims to do so by building on the current body of knowledge. While academic research on motivators and inhibitors to conference attendance is well established and a number of conventionally significant factors have been identified, this paper aims to contribute in two main ways. Firstly, it introduces motivators and inhibitors deriving from contemporary industry reports which are added to those deriving from academic research, offering a more holistic view. Secondly, it ranks such variables in order of importance, rather than identify the factors that are significant such as previous studies. The ranking of factors in order of importance to delegates helps destinations identify which factors deserve most investment of resources and thus act as guidance on the best ways to direct their limited resources by prioritising accordingly. This study thus explores the importance of motivators and inhibitors that have not been previously documented in detail in academic research, while reconfirming which of the traditional variables are still considered to be important. Contemporary delegate expectations related to new as well as traditionally-important factors are identified and explored in this paper, while strategies to tackle them are proposed. Such updated knowledge is of extreme importance to key industry suppliers such as conference agencies (Hayat, Severt, Breiter, Nusair \& Okumus, 2014), host locations, conference centres and conference bureaus (Jago \& Deery, 2005) in order to shape their strategies and attract conference tourism. This knowledge is also of interest to the hospitality sector in general (Henderson, 2007) and the generic suppliers at the destination as all are set to benefit from this industry through its ripple effects (Lee et al., 2013).

The conference sector is vast and has been traditionally segmented according to the characteristics of the initiator (Rogers, 2013). Three main conference types have 
been identified as association, corporate and government (Mair, 2013). Corporate meetings are business-related meetings held by private companies (Rogers, 2013); government conferences are high profile summits and training meetings for civil services (Mair, 2013); while association conferences are conferences on subjects of common interest to members (Rogers \& Davidson, 2015). This paper focuses on the association market as it is considered an important growth market (Mair, LockstoneBinney \& Whitelaw, 2018), with larger delegate numbers (Rittichainuwat, Beck \& Lalopa, 2001) and since, unlike their counterparts, association delegates choose to attend conferences voluntarily (Mair \& Thompson, 2009; Rogers, 2013). This makes understanding delegates' perceptions a necessity for any stakeholders interested in association conference tourism.

The association market is further sub-divided into different conference types. Associations may vary, including professional and trade associations and philanthropic or charitable organisations (Hahm, Breiter, Severt, Wang \& Fjelstul, 2016). The associations sector may also include buyers from the Social, Military, Educational, Religious and Fraternal (SMERF) sectors (Holloway, Humphreys \& Davidson, 2009). While this leads to variation within the segment (for example in the duration of conferences) the average duration of an international association conference, is around 3-5 days (Rogers, 2013). A number of other similarities between associations include the fact that every specialisation has an association, organising regular meetings that are held in different countries and choose a location mostly based on the efforts of the association's local chapter at such destination. The lead time for such conferences is long, and may be over five years (International Congress and Convention Association, 2018). 
Another central feature of association conferences is that they are larger in delegate size (Hahm et al., 2016; Rogers, 2013). Association members are charged to attend the conference, making them a source of income for the association (Hahm et al., 2016; Mair \& Thompson, 2009). Organisers aim at maximising attendance in order to increase the profit margin (Rogers, 2013). The association delegates become the conference's end clients (Tanford, Montgomery \& Nelson, 2012) but attracting them might be challenging as a delegate typically belongs to multiple associations (Tanford \& Montgomery, 2015). With the reduction of sponsorship and travel funding for delegates this segment has increased in competitiveness (Cró \& Martins, 2018). Therefore, understanding the complexity of the factors involved in attracting delegates to attend becomes very important (Lee \& Fenich, 2016).

\section{LITERATURE REVIEW}

Knowledge of the association delegates' characteristics and perceptions is essential for conference organisers, who in turn select the conference destination. Different visit behaviours need to be understood, so that the organiser may act accordingly to utilise the right strategies to increase delegate attendance (Kim \& Malek, 2017; Tretyakevich \& Maggi, 2011). Ramirez, Laing and Mair (2013) identify three main categories of drivers in participation decision-making. Firstly, motivators are what attract the delegates to a conference destination and are the positive outcomes of attending. Secondly, facilitators and inhibitors are factors that help or hinder the delegate's decision to attend. Inhibitors are considered barriers to attendance while facilitators are any variables that make attending a conference easier. Finally, the influence of third-parties may also affect the delegate's decision-making process, just as in the case of leisure travel decision making (Sparks \& Pan, 2008). Families and 
spouses have a stronger influence, especially if the potential delegate is married and/or is frequently away (Ngamson \& Beck, 2000; Rittichainuwat et al, 2001). Managers and colleagues may also have the same effect on the decision making (Lee \& Back, 2007). In this study the term motivator shall be used to refer to variables attracting delegates to attend a conference, while the term inhibitor shall refer to all the barriers to conference attendance.

\section{DESTINATION-RELATED FACTORS}

The destination acts as a significant motivator for the conference delegate (Skinner, 2017) and a number of destination-related variables have been identified as important factors in influencing conference attendance (Mair et al., 2018). Conference facilities have frequently been highlighted as important (Bernini, 2009; Crouch \& Ritchie, 1998; Crouch \& Weber, 2002), with special preference given to the 'convention environment' which includes venue and facility-focused attributes (Jung \& Tanford, 2017). Generally, conference facilities require the development of a hotel and catering industry to accompany it (Marques \& Santos, 2016). Furthermore, the destination needs to be accessible (Lee \& Park, 2002) as lack of accessibility acts as an inhibitor (Horváth, 2011; Mair \& Thompson, 2009). Accessibility includes different dimensions: cost, transportation mode options and frequency, proximity of the destination to its markets and travelling time as well as travel formalities (Donaldson, 2013; Crouch \& Weber, 2002; Zhang et al., 2007).

Favourable climate also gives a competitive advantage to the destination (Jung \& Tanford, 2017; Zhang et al., 2007). Undesired weather conditions act as inhibitors, and thus require mitigation when possible. For example, the Orlando Orange County Convention and Visitors Bureau (OOCCVB) offers hurricane insurance. This covers the 
conferences being held at the destination during the bad weather period, putting the planner's mind at rest when booking and planning a future conference (Hayat et al., 2014).

Competing in the conference tourism market requires the right image and positioning to be held by the destination (Jung \& Tanford, 2017; Marques \& Santos, 2016). Destinations associated with the arts, cultural heritage or business in general are more attractive to conference delegates and organisers (Bernini, 2009). A history of hosting conferences further helps to improve a destination's attractiveness through the opportunity to showcase a number of qualities (Chiu \& Ananzeh, 2012; Lee, 2006). Meetings provide the opportunity to promote the destination on an international level (Hanly, 2011) while delegates themselves act as ambassadors promoting the destination (Severt et al., 2007).

Safety also plays a key role in attracting conference tourism, as delegates are afraid to travel to unsafe destinations. The level of safety at a destination depends on violence, crime, terrorism and the extent to which security is available at the destination (Cró \& Martins, 2018). Conference organisers are very risk-adverse and threats such as terrorism can result in the destination no longer being attractive to the conference organiser for a period of time (Avraham, 2015; Baytok, Soybali \& Emir, 2010). Frequent crises may lead to a destination or geographical region to become an unattractive conference location altogether. The Middle East, for example, has been perceived as ‘dangerous, violent and prone to terrorism’ (Al-Mahadin \& Burns, 2006). Such "spillover effects" may be due to media bias or the delegates' lack of geographical knowledge about the area (Taylor, 2006). 


\section{DELEGATE-RELATED FACTORS}

There are also non-destination-related motivators and inhibitors that influence the delegates' decision to attend a conference. Motivators may include the individual's involvement in the association hosting the conference, the ability to receive external funding for attendance, the time availability (Jarumaneerat, Al-Sabbahy \& Jones, 2007; Mair et al., 2018) and to the opportunity to visit a location and possibly friends and relatives living there (Jung \& Tanford, 2017; Ramirez et al., 2013; Superio \& Anderson, 2016).

On the other hand major inhibiting factors include health of the individual, past experiences and travel ability (Jarumaneerat et al., 2007; Lee \& Back, 2007; Mair \& Thompson, 2009; Severt et al., 2007) and personal budget (Ramirez et al., 2013). Costs have in fact always been considered an inhibitor to attendance, especially as association delegates are self-financed (Mair \& Thompson, 2009). Cost is considered to be a negative predictor of attendance at a conference (Mair \& Thompson, 2009; Tanford, 2012), and an intervening opportunity that acts as an inhibitor to attendance (Oppermann \& Chon, 1997). The cost factor is composed of four main attributes including transport expenses, accommodation expenses, food and beverage expenses, and commodity prices (Filipović, 2012). Furthermore, Zhang et al. (2007) have added the time-cost to the traditional monetary cost within what they define as the total cost factor of attending a conference. In relation to accommodation cost, Crouch and Louviere (2004) argue that the host location's attractiveness decreases as room rates increase, independent from quality. Dioko and Whitfield (2015) disagree, showing that cost should not be considered as an automatic inhibitor. They suggest that when value is high, costs would not act as an inhibitor. 


\section{CONFERENCE-RELATED FACTORS}

Conference-related factors have also been identified in academic literature. Delegates are attracted by the potential of educational improvement, career enhancement and the prospect of developing new skills (Mair \& Thompson, 2009; Ramirez et al., 2013; Severt, Wang, Chen \& Breiter, 2007; Zhang, Leung, \& Qu, 2007). Networking and socialising have also traditionally acted as motivators to attendance (Tanford et al., 2012; Yoo \& Zhao, 2010).

Furthermore, delegates expect the provision of leisure-related activities (Bernini, 2009; Hanly, 2011; Tretyakevich \& Maggi). The delegates may engage in leisure activities during official social programmes or by extending their stay at the host destination. Association conferences usually include pre- and post-conference periods for this matter (Donaldson, 2013).

While a number of variables identified in literature and discussed in this section have retained their significance over time, other variables have been considered to be of less importance for the contemporary delegates' needs. This study confirms which variables still retain their importance and which have lost in importance vis-a-vis more contemporary important variables. With the inclusion of variables deriving from current industry reports and primary industry experience, this study aims to provide a reliable list of contemporary motivators and inhibitors that shape delegates' conferenceattendance decision-making process and may thus help form conference tourism stakeholders' marketing strategies and plans. 


\section{METHODOLOGY}

The main aim of this study; to identify the level of importance of motivators and inhibitors that influence delegates' conference attendance, was identified to be in line with the principles of the quantitative approach. The quantitative study's goal is to develop a generalisation that contributes to theory and enables the researcher to predict, explain and understand a phenomenon (Abawi, 2008), and this element of prediction is what made quantitative methodology attractive. Quantitative methods also allow preference ranking, which was required in order to produce the ranking system showing which motivators and inhibitors are important and which are not. A self-administered questionnaire was thus chosen to collect the required data. This method has been used in similar studies such as Baloglu and Love (2005) and Mair and Thompson (2009).

The questionnaire was split into two main sections. 'Section A' focused on the variables that affect the delegates' decision to attend a conference at a particular destination. The generic concepts of motivators and inhibitors were broken down into a list of specific variables to ensure each variable is clearly understandable to respondents (White, Jennings, Renwick \& Barker, 2005). Such variables were extracted from different sources, which include past academic literature, industry reports and one of the author's direct experience as conference organiser. This promised to produce an up-todate factor ranking system which combines academic and industry knowledge and understands the contemporary requirements of association delegates. This section was split into two sub-sections; motivators and inhibitors to conference attendance. It included a total of 144 variables of which 82 were potential motivators and 62 potential inhibitors to attendance. 'Section B' sought to gather background and demographic information from participants. Different rating scales were considered but the Likert scale, using 5 points, was preferred over the bigger scales such as Tannebaum's (7- 
point-scale) and Thurstone's (11-point-scale). This was since it gives the necessary range of options without being too long a scale to compromise its clarity. Each point added is another point to be interpreted by the participant increasing the chance of inconsistency over time or across individuals (Krosnick \& Presser, 2010). A mid-point was also included as one of the options, in order to ensure that respondents who genuinely feel neutral would not be forced to pick a positive or a negative side of the scale, as this would result in inaccurate measurement. Response scales without a middle point have been shown to have lower validity and higher random error variance (Saris \& Gallhofer, 2007). The questionnaire was four pages long and was printed on a folded A3 sheet in order to make it easier to flow from one page to another for the participants.

The research was carried out in Malta, which is the country of residence of one of the authors. Respondents needed to satisfy one specific characteristic; having attended at least one international association conference as a delegate over and above the one being attended in Malta to ensure that this conference was not their sole experience as a delegate. This measure was also taken to ensure that the responses would not just be based on the delegate's motives behind attending the conference where data collection was carried out, but that it would reflect their experience as delegates in general. In order to ensure this requirement was satisfied, participants were thus asked to confirm they had attended at least one other international conference prior to the one where the questionnaire was taking place. Non-probability sampling was identified as the only practical sampling technique (Gantz, 2015) enabling the questionnaires to be undertaken when and where conference delegates were available. Five international association conferences held in Malta were thus identified and consent to carry out data collection within the conferences was secured from all five of 
them. The conferences, held in the cities of Qawra, St Julians and Valletta, included a Medical Conference of approximately 1000 participants spanning on six days, a Law Conference of approximately 400 delegates spanning on four days, a Leadership Conference of around 150 delegates spanning on two days, a 30 delegates' international seminar of two days, and a three-day Political conference hosting 250 participants. In each case, delegates were members of the association hosting the conferences and were not compelled to attend. In fact, they were responsible to cover the conference fees and costs themselves. This ensured that no delegates' attendance was mandatory. All conferences were held during 2016 and 2017. Each conference was hosted at a hotel whereby the association made use of the in-house conference facilities in each case except for the political conference that was hosted at a conference centre that was also interconnected to the association's main accommodation hotel.

The self-administered questionnaire was made available at main intercept locations throughout the whole duration of each international conference. Intercept locations within the conference venues included the main conference room lobby and foyer, allowing participants to be recruited immediately after their experience with the conference event (Validity Research, 2015). This guaranteed the availability of the target audience at the location (Sukamolson, 2007). The questionnaire was selfadministered, but researchers briefed potential respondents about the study and made themselves available throughout the process. This allowed the research team to highlight the importance that the responses should reflect the general experience as association conference delegates rather than just the experience at the conference were data collection was held. It also allowed participants to ask any questions they might have had (Fowler, 2013). 
In total, 270 usable responses were collected. Delegate participants originated from 72 different countries around the world with female respondents constituting 55\% of the participants. The respondent group was predominantly within the twenty-two to thirty-five age cohort (58\%) and most respondents had a college level of education (53\%) or a degree (26\%). The largest cohort (35.5\%) of respondents stated they attend international conferences once to twice a year.

Data collected was analysed using the Statistical Package for the Social Sciences (SPSS) software. Factor Analysis tests were carried out on the topmost important motivators and barriers (mean $\geq 4$ ) in order to examine the structure of the top factors affecting conference attendance decision making and has been used in similar studies (Yoo and Zhao 2010; Tanford et al. 2012; Rittichainuwat et al. 2001). Orthogonal rotation (VARIMAX) and Kaiser Normalization were employed, as this approach was considered to yield more interpretable results (Loker and Perdue 1992).

\section{FINDINGS AND DISCUSSION}

Ranking the motivators and inhibitors by importance enabled the understanding of which factors can be considered the most important for delegates when deciding whether to attend a conference. Due to the large number of variables, factor analysis was employed in order to single out the few most important factors that deserve to be prioritised.

\section{FACTOR ANALYSIS}

A Factor Analysis was carried out separately for the motivators and the barriers. For the motivator variables, the Kaiser-Meyer-Olkin Measure of Sampling Adequacy showed a value of (.660) (Table 1) which was considered adequate (Tabachnick and Fidell 1996). In order to obtain theoretically meaningful factors, only the higher loading 
variables (from 0.59 upward) were considered when grouping the components. This indicated a strong correlation between the variable and the component group. Due to the strong loading, interpretation of factors was easier, and four main categories were identified. These included educational experience; conference factor, technology and socialising. Each category included at least one highly-ranked motivator variable. These are presented in Table 2.

Table 1 - KMO and Bartlett's Test - Motivators

Kaiser-Meyer-Olkin Measure of Sampling Adequacy.

Bartlett's Test of Sphericity Approx. Chi-Square

.660

df

Sig. 503.640 000

Table 1. KMO and Bartlett's Test - Barriers

Table 2 - Factor Analysis Results for Motivators

\begin{tabular}{|l|r|r|r|r|}
\hline \multicolumn{1}{|c|}{ Variables } & \multicolumn{3}{|c|}{ Component } \\
\cline { 2 - 5 } & $\begin{array}{c}\text { Educational } \\
\text { experience }\end{array}$ & $\begin{array}{c}\text { Conference- } \\
\text { related }\end{array}$ & $\begin{array}{c}\text { Technology- } \\
\text { related }\end{array}$ & Socialising \\
\hline $\begin{array}{l}\text { Interesting conference program } \\
\text { Topic of personal interest } \\
\text { Develop new skills }\end{array}$ & .689 & .653 & & \\
$\begin{array}{l}\text { Education improvement } \\
\text { Socialise and making new } \\
\text { friends }\end{array}$ & .665 & & & \\
Fast Wi-Fi availability in \\
general
\end{tabular}

Table2. Factor analysis results for motivators 
A similar process was carried out for variables related to barriers. The KaiserMeyer-Olkin Measure of Sampling Adequacy showed a value of (.775) which was also considered adequate (Table 3). In this case, the group components were easily distinguishable and a loading of 0.60 was considered adequate. No variables were removed. The component factors identified were technology, safety, sanitation and cost and are shown in Table 4.

Table 3 - KMO and Bartlett's Test - Barriers

Kaiser-Meyer-Olkin Measure of Sampling Adequacy.

Bartlett's Test of Sphericity

Approx. Chi-Square

$\mathrm{df}$

Sig.

Table 3. KMO and Bartlett's Test - Barriers
885.827

28

.000

Table 4 - Factor Analysis Results for Barriers

\begin{tabular}{|c|c|c|c|c|}
\hline \multirow{2}{*}{ Variables } & \multicolumn{4}{|c|}{ Component } \\
\hline & Technology & Safety & Sanitation & Cost \\
\hline $\begin{array}{l}\text { Lack of Wi-Fi availability at } \\
\text { accommodation } \\
\text { Sanitation problems at } \\
\text { accommodation } \\
\text { Lack of Wi-Fi availability at } \\
\text { conference venue } \\
\text { Slow Wi-Fi connection at } \\
\text { conference venue } \\
\text { Terrorism threat at the destination } \\
\text { Safety at the destination } \\
\text { Sanitation at destination } \\
\text { High accommodation cost }\end{array}$ & $\begin{array}{l}.798 \\
\\
.850 \\
.880\end{array}$ & $\begin{array}{l}.886 \\
.889\end{array}$ & .629 & .969 \\
\hline
\end{tabular}

Table 4. Factor Analysis Results for Barriers 
Having identified the most important variables, it was clearer to understand which conventionally strong variables remained strong and which have lost in importance. Furthermore, emerging factors could also be identified.

\section{CONSTANT FACTORS}

A number of factors have clearly retained their importance in delegates' decision-making and should continue to inform conference organisers' plans and strategies. Nonetheless, modern delegates' expectations vis-à-vis such traditional factors might have changed or increased and should thus be viewed with caution. Reconfirming the importance of a motivator or inhibitor does not signify lack of change but should, on the contrary, make stakeholders question what recent changes may be effecting expectations related to such factors. This section shows how a number of factors have retained their importance, or increased it, while it also reconfirms that what would have satisfied such factor-related needs in the past might not satisfy them today.

The topmost important factor is Wi-Fi. Wi-Fi was a technology factor that was identified as very important, both as a motivator and an inhibitor. Rather than being important, Wi-Fi has emerged as being a necessity. Delegates have a high level of expectation of this service, and slow Wi-Fi is not acceptable. This was made explicit by $87.8 \%$ of the delegates who considered it to be important or very important. Wi-Firelated inhibitor variables were also important to delegates. Both lack of Wi-Fi availability at the conference venue (mean= 4.51) and slow Wi-Fi connection at the conference venue (mean= 4.35) were unacceptable. Past research amongst Millennials (Fenich, Scott-Halsell, Ogbeide \& Hashimoto, 2014) also identified that a proportion of the delegates strongly expected the availability of Wi-Fi (Asian Millennials; mean = 4.51), while others did so to a lesser extent (African Millennials mean= 3.65). In this 
study Wi-Fi was considered essential by all of the delegate population. Previous studies have also shown that whenever Wi-Fi was lacking, delegates were dissatisfied (Hussain et al., 2014). Industry reports also confirm Wi-Fi is a top priority and that enough WiFi bandwidth to meet attendee's needs is specifically requested (Palmer, 2018). The findings presented show that delegates expect fast Wi-Fi to be available throughout the destination, conference venue and accommodation venue and will consider anything less as an inhibitor. While Wi-Fi has been recently considered important, the high level of dependence on Wi-Fi (fast $\mathrm{Wi}-\mathrm{Fi}$, to be available everywhere) is to be taken into consideration by stakeholders such as destination, organisers, conference venues and accommodation providers.

This study has also reconfirmed the importance of time and work commitments, which have also emerged in previous studies (Ramirez et al., 2013), and which comes out of a number of variables classified as important. Delegates highlighted the importance of having an environment that is suitable to work at the accommodation (mean= 3.89) as well as the time-related challenges to attend due to a conference being advertised too late to fit in their schedule (mean= 3.88) and the problems they find to take time away from work (mean= 3.77). The increased need for flexibility emerges from these results and indicate the importance of flexible or shorter conference agendas to help make the conference commitment easier for delegates. Conference organisers should also inform potential delegates of the date of the conference way in advance, in order to allow delegates to plan their participation accordingly (Ramirez et al., 2013). Due to busy lifestyles, attending the whole conference can prove challenging to association delegates who, unlike corporate delegates, are required to attend during their personal free time. Delegates should be able to attend only the days or sessions that fit their personal schedules by including day or session-packages for example. Unless such 
flexibility is catered for by conference organisers, a risk of decreased physical attendance exists. This risk is exacerbated by the forecast increase in conferences' virtual attendance, expected to grow by $2.6 \%$ (Meeting Professionals International, 2017).

A list of educational and career-related benefits re-emerged as important motivators. Delegates sought to develop new skills (mean= 4.34); work across cultures (mean= 4.20); gain from education improvement (mean= 4.18); seek career enhancement (mean= 4.00), develop international reputation (mean= 3.93) and keep up to date on latest issues (mean= 3.88). These variables can be classified as the reasons behind organising conferences in the first place, whereby a main aim is always to ensure that attendees can utilise the knowledge being transferred to them to improve themselves. Furthermore, certain delegate profiles are specifically attracted to the conference's educational agenda, speakers and content of sessions (American Express Meetings and Events, 2018). Conference organisers should promote keynote speakers and educational benefits early to attract such delegate cohorts.

The pull factor of the conference itself remained strong. Topic of personal interest (mean= 4.35) ranked highly with $91 \%$ of delegates considering it to be important or very important. The conference programme also attracted delegates, with $88 \%$ of delegates considering an interesting conference programme (mean= 4.28) as important or very important. This result re-confirms the importance of such traditional factors and is expected for association conferences, since membership within the association itself would be related to a common interest that would heavily influence the conference topic (Rogers, 2013).

Nonetheless, delegates’ expectations are now going beyond traditional factors. Tailor-made programmes have become essential (Tretyakevich \& Maggi, 2011). 
Modern attendees' expectations include having control over what activities delegates opt into, making them feel that the conference was actually built around them and constituting a personalised experience (Destinations International 2017 Report). Different delegate profiles are attracted by different topics and these should therefore be made available. Augmented technology allows for the provision of multilateral means of communications and thus helps gearing the conference more towards each attendee's needs (German Convention Bureau 2013). This requires a choice of activities (such as networking sessions), attractions and locations for delegates.

A phenomenon described by Oates (2017) as the 'festivalization of events' is in fact shaping the programming of conferences, whereby different type of events are added to the conference itself such as a concert or festival, aiming at immersing the delegates within the whole event experience. Thus the programme of the conference does not need to be conventional and should, on the contrary, ensure that delegates have an unforgettable experience. Being a once-in-a-lifetime experience and offering attendees an experience that cannot be accessed if they are visiting the destination on their own is a necessity as delegates seek to attend conferences for the experiences they provide. Experience has been named the "new status symbol" (Natasha Syed in Palmer, 2017, p.1). Experiencing the conference is another reason, together with physical networking, which attracts the delegate to be physically present at a conference, rather than attending virtually or accessing the information being delivered by speakers online (Davidson and Turner, 2017).

The association's pull-factor also remained strong. Delegates were interested in influencing the organisation's future direction (mean= 3.97), hence they wanted to be present at its conferences. Furthermore, positive past experiences of attending a conference by the same association (mean=3.92) was also considered important and 
shows the loyalty element of delegates towards their association. This should be capitalised upon by the organiser as a main tool of attracting repeat delegates (Tanford and Montgomery, 2015) and reinforcing once again the idea of loyalty towards the association. Such result show the delegates' strong personal interest in following the association. A strong pull factor of the association could mean that the association is in reality more flexible in choosing its conference destination, since its delegates are increasingly loyal. In that case, destinations should shift their marketing efforts to the associations directly, in order to build early alliances before associations start shopping around for options. This is because the association on its own is strong enough to attract a good level of attendance from its members.

Cost remains one of the main conference conventional inhibitors. Different dimensions of costs related to accommodation (mean= 4.19), registration (mean= 3.95) and travelling (mean= 3.80) were all highlighted as important. This study also showed that discounts on expenses, such as travelling, were much less attractive (mean=3.31) than having such costs completely covered (mean= 3.80).Conference organisers need to ensure that delegates get the right value for their fees. Selecting destinations with ease of access would also help mitigate the travel costs while conference registration costs need to be worked out according to the delegates' socio-economic characteristics. It is expected that planners will need to look for innovative, cost-effective solutions to provide the "wow effect" that delegates are seeking (Palmer, 2017) and ensure the experience being offered warrants the fees being requested. One such way could be utilising new sites offered by secondary or tertiary conference destinations that has been considered to be a new trend within the Destination NEXT (2017) report.

Cleanliness also retained its importance amongst delegates. Cleanliness in general (mean= 4.32), at the destination (mean= 4.29) and at the accommodation 
(mean= 4.32) was considered important. While cleanliness and hygiene have been repeatedly and widely mentioned in studies (Dwyer \& Kim, 2003, Wan, 2011), most studies have shown that delegates consider hygiene as a pre-requisite and take it for granted. Thus, if a destination is perceived as clean, it is unlikely to lead to a positive attendance rate, while a shortfall may undermine the decision to attend (Yoo \& Zhao, 2010). This study has indicated that delegates classified cleanliness as an important motivator, over and above being an important inhibitor, indicating the increased importance of this factor.

Personal factors continue to play an important part in attendance decisions. These include the traditional inhibitors being health problems (mean= 3.71) and family obligations (mean= 3.67). Cost also remains important, as discussed previously. These factors are difficult to predict or control by the organiser or destination, as they are specific to each and every delegate. On the other hand, obtaining an average profile of the potential delegate market could help organise a conference that is more 'friendly' to the needs and limitations of its delegates.

\section{LESS IMPORTANT FACTORS}

A number of factors that have been extensively discussed in past research have been considered as less important to the delegates when compared with other factors. Thus this questions their level of importance to the contemporary delegate. It must be understood that even though these factors are relatively less important compared to the other factors proposed to the delegates, it does not mean that they are non-important.

The accommodation venue is one such factor. A number of factors at the accommodation venue such as $\mathrm{Wi}-\mathrm{Fi}$, cleanliness, cost and availability for work and networking have been listed above and can be considered to be of high important. High 
service quality at the accommodation venue (mean=3.96) was also considered important. On the other hand, a number of other related variables were considered of less importance, such as accommodation to be at a known hotel (mean=2.67), the possibility of gaining loyalty points at accommodation (mean= 2.70), remote climate (2.75) and remote check-in (2.82) at accommodation. Leisure and down time activities at the accommodation were also not considered highly important. These included the availability of gym, sauna and spa (mean=2.84), as well as leisure facilities at the accommodation (mean=3.20) and entertainment facilities close by (3.22). Furthermore, and possibly linked to both high service quality and technology, quick response customer care service (mean= 3.44) was considered moderately important variable. Such result also confirms the increased expectation of fast response to delegates' demands that may be handled by apps and conference technology. Three star or higher accommodation was also preferred (mean= 3.57) re-confirming that delegates expect value from their accommodation, and identifying a minimum standard expectation (three star). Thus while a number of platforms have made different type of accommodation, including self-catering available to delegates, these will still be required to be of certain standard to contribute to the destination's conference tourism product.

Similar moderate importance was given to the conference venue, whereby only one factor was ranked as very important - a short distance to the conference facility from accommodation (mean= 3.90). On the other hand, some other less important variables indicate what are the delegates' expectations vis-à-vis the conference venue. Delegates expect increasing control over the environment they spend time at, for example in terms of climate control (motivator: mean= 3.45; inhibitor: mean= 3.38 ) and suitable lighting at the conference venue (mean= 3.62). Such variables are to be 
considered as a required standard when planning conference venues in order to ensure that they have control over the venue's environment during conferences. These include décor, ambiance, lighting, signage, temperature control, aesthetics equipment and employee uniforms (Crouch \& Weber, 2002). Organisers will look for venues that fit the theme of their event (Whitfield, 2009), and thus the more flexible a venue, the better placed it is to attract conferences. Conference venues also require flexibility, to accommodate previously discussed requests such as delegate networking and engagement. In this regard, fixed seating may no longer be requested and focus may move towards lightweight flexible seating that allow attendees to move between large group to small group activities (German Convention Bureau, 2013). Venues need to be able to switch effectively between three main set-ups for knowledge transmission, mainly auditory, visual and collaborative as $60 \%$ of the operators claim that the flexible non-traditional meeting room furniture can be considered one of the biggest trends in meeting venue development and design (International Association of Conference Centres, 2018). Conference venues need to be ahead of such trends. Other upcoming trends may also be identified, such as 'Healthy Venues' an accreditation that has already been endorsed by venues such as the Scottish Event Campus, the Vancouver Convention Centre and the Convention Centre Dublin (Davidson and Turner, 2017).

No direct destination-related variables ranked amongst the top factors. This reflects the results of the study by Superio and Anderson (2017), whereby destination stimuli also ranked very low. Nonetheless, delegates did show a (less important) interest in destinations if they are visiting them the first time (mean= 3.59). This result also relates well with the observation made by Skinner (2017) regarding novel destinations, whereby delegates will be more interested to attend a conference at a destination that they would not visit otherwise (Skinner, 2017). Furthermore, cultural 
and historic attractions at destination (mean= 3.62) were also considered relatively important (in comparison to other destination-related motivators). Conference organisers could thus combine this with the interest in networking and organise networking and social events at cultural and historic sites. Alternatively, organisers might consider the possibility of utilising historic sites to organise the conference altogether, although this might be challenging since most historic buildings would not have been built with the intention of hosting conferences. Organising and promoting pre- and post-conference events might also serve to satisfy the delegates' need to explore local attractions. These results may also be an indicator that destinations are losing their pulling-power and thus require the increased promotion and upgrading of any unique selling point a destination might have.

Environmentally-related factors were considered of high importance by delegates. Factors such as conference environmental-friendly activities (mean= 3.09), environmentally-friendly transport (mean= 3.07), environment-friendly freebies and merchandise (mean= 2.94), using only recyclable items (mean= 2.91) and an ecocertified venue/ accommodation (mean= 2.91) ranked relatively low. Nonetheless these results might still not contradict pro-environmental statements that green practice may provide a competitive advantage for conference organisers (Han, 2014). While green practices may still not be attractive to the majority of the delegates, they attract proenvironmental groups of delegates. This was true in the case of Ranacher and PröbstlHaider (2014) who showed that while 99\% of the delegates in their study considered environmental efforts as positive, only 39\% of the attendees knew prior to arrival that the conference they were attending was eco-certified. Similarly, in the current study, delegates were in general agreement that eco-friendly measures are positive, but to date they are not sufficiently interested in them. Conference organisers, venues and 
destinations should explore green meetings further, and develop effective ways of marketing any eco-friendly measures that they have adopted and their benefits (including monetary). Meetings and Conventions 2030 (German Convention Bureau, 2013) in fact predicts that sustainable development will become an important quality factor and criterion in choosing conference locations and will be a crucial advantage in the competition among event venues and destinations (German Convention Bureau, 2013).

\section{RECENT FACTORS}

This study has identified a number of factors that have been very briefly listed or discussed in previous studies, but that have been identified as important for the contemporary delegate in the conference decision-making process. Such factors have become important just recently or have not been covered in previous literature at all. While some are linked to traditionally important factors, they extend into expectations and areas that were not considered previously important or even discussed.

In terms of technology, Wi-Fi was not the only factor identified as important. In this study $82.9 \%$ of the delegates considered power supply availability for devices (mean $=4.25)$ to be important or very important. This variable's importance was reconfirmed by its related inhibitor counterpart - lack of power supply for devices at conference venue (mean= 3.96) high ranking amongst inhibitors. This topic was mentioned in an industry report- Meetings and Conventions 2030 (German Convention Bureau, 2013) that identified power supplies as one of the requirements for the contemporary delegate but also indicated that delegates in 2030 will not be dependent on them anymore, thanks to advances in technology (German Convention Bureau, 
2013). Nonetheless, at present venues need to ensure the provision of power supplies until the necessary changes in technology occur.

Access to conference agenda or schedule from delegate's devices (mean= 3.96) was also considered attractive by delegates, with $75.5 \%$ classifying it as important or very important. While there is no record of this specific variable in academic literature, app adoption in conferences may be classified as relatively recent as it was one of the most significant conference technology developments in 2017, and likely to grow as apps are increasingly utilised in attendee management, registration and post-event contact (Palmer, 2018). Furthermore, social media will also supplement the use of apps, as it has already been used in a multitude of ways, such as for communication amongst delegates and for marketing conferences by organisers (Destinations International, 2017), delegate engagement (Davidson \& Turner, 2017), and for use in case of emergencies and crises during conferences (BCD Meetings \& Events, 2017).

It is evident that while some aspects of technology have not been regularly listed in academic literature, they are now considered a requirement, or rather pillars of conferences, and less as a driving force of change (Oates, 2017). In terms of use in conferences, the current trends indicate that artificial intelligence, virtual reality and chatbots are potentially the top advantages to watch, but conference planners should strive to include such technology only if it adds value to the conference and if it serves a purpose (Palmer 2018).

Networking opportunity (mean= 4.21) and socialising and making new friends (mean= 4.04) are traditionally important motivators that have been reconfirmed as important. On the other hand, the results in this study show that expectations in terms of networking have now increased and become extended to related variables, whereby new motivators have emerged. These include networking spaces at accommodation venue 
and networking spaces at conference venue (mean= 3.60 and mean= 3.59 respectively). The inclusion of such variables indicate that networking is becoming even more important and delegates expect that the conference environment acts as a conducer and facilitator of such.

This has also been highlighted in industry reports whereby suitably equipped meeting locations for networking are considered a prerequisite (German Convention Bureau, 2013). Networking and attendee engagement is becoming increasingly important to motivate delegates to physically attend the conference with face-to-face meetings demonstrated to be more effective than virtual meetings (Pittman \& McLaughlin, 2012). It has also been empirically shown that there is a positive relationship between networking and attendees' conference behavioural intention (Jung \& Tanford, 2017). Furthermore, networks are recognised to be a key part of a successful career (Mair \& Frew, 2016), which links its importance to career-related motivators previously discussed. Thus networking is shaping the layout of conference sessions whereby forum type settings that allow interaction and exchange of ideas are becoming increasingly popular over plenary sessions (BCD Meeting and Events Trend Report, 2017). Conference venues are also offering more collaborative and networking spaces outside of meeting rooms and making use of public spaces for increased networking (IACC, 2018).

Conference programmes should allow time and the ideal space for both formal and informal networking amongst participants and speakers with dedicated time-slots and at venues that are specifically set up to facilitate networking. Networking may also be facilitated through conference technology such as by mobile apps (American Express Meetings and Events, 2018). Nonetheless, physical networking should be given priority, as it is associated with higher performance and productivity (Mair et al., 2018; Yoo \& 
Chon, 2008). Such variables should be included and highlighted in the process of promoting the conference to increase the conference's physical attendance. While transition of knowledge can be easily carried out virtually, attendees look forward to benefiting from activities that are best carried out in person such as networking, which also enhances their experience of attendance (Davidson \& Turner, 2017).

Safety was also identified as one of the top inhibiting factors in this study. Safety at the destination (mean $=4.18$ ) had $83.1 \%$ of the delegates ranking it as important or very important while the terrorism-specific variable (mean $=4.00$ ) had $76 \%$ of the delegates considering it to be important or very important. Terrorism in neighbouring country (mean= 3.66) was also considered an important inhibitor. Safety concerns are a common inhibitor (Donaldson, 2013; Tanford et al., 2012) and the IBTM Trends Watch Report 2017 also reaffirm this, as effects of natural disasters such as hurricanes in the US were stated to have a negative impact on confidence of conference destination decision makers in the association market (Davison \& Turner, 2017). Its importance has increased due to the constant natural disasters and man-made attacks occurring and has become the only area in conference planning where planners are seeing their budgets increase (Palmer, 2018) due to increased need of security and insurance covers.

The main emerging trend related to safety is the strong increase in importance given to variables directly related to terrorism (and terrorism in neighbouring countries). These indicate that terrorism has become a major concern for delegates in terms of image and perception. The results strengthen some literature findings, whereby terrorism acts dominate the perception of the destination, making it unattractive (Avraham, 2015) and removing it from the list of conference destination alternatives until the act is forgotten (Avraham, 2015; Baytok et al., 2010). Heightened concern 
about terrorism may be related to increased terrorism attacks in Europe, the continent which hosts most association conferences (as per Union of International Associations, 2018). Destinations have to work harder to counter negative images, possibly by increasing security drastically. Any other method such as the use of public diplomacy has been shown to have a limited effect (Taylor, 2006). Nonetheless, destinations may be successful in re-building their image as being safe such as in the case of Paris, which returned to the number one destination for conferences in ICCA statistics in 2016, after it had lost its place to Berlin in 2015 due to terrorism attacks. This was considered a remarkable feat by Paris given the negativity of security concerns related to the city, and proof that the destination's efforts had been successful (Davidson \& Turner, 2017).

This study's results also show that terrorism has a wide geographical effect in terms of image (Al-Mahadin \& Burns, 2006). When such a perception exists, each incident reinforces the negative image of the region, even if crises occur only in just one country within that geographical region (Taylor, 2006). On the other hand the effects of general instability (as opposed to terrorism) seem to be less strong over geographical boundaries (mean= 3.32) with only half of the delegates considering it to be an important or very important inhibitor (50.2\%). Having discussed the strength of media in such spill-over effects, the sensational coverage of terrorism attacks has possibly made delegates more concerned about terrorism than other dangerous situations.

Alternatively, delegates could consider instability in other countries to be more of a local issue rather than an international one. Instability and uncertainty occurring at the source destination of potential delegates may on the other hand also have a great influence on attendance. UK delegates have for example taken a step back in attending conferences related to EU or being EU funded, due to the current uncertainty of the effects of Brexit. This is considered to have potential negative implications for the 
association market, even though it is still too early to identify or forecast any related trends (Davidson \& Turner, 2017).

Further research is needed to explore other dimensions of security. Digital security is one such dimension (Palmer, 2017). The virtual person that is represented by their data is as important as the physical protection in large gatherings (German Convention Bureau, 2013). Safety concerns may result from potential lack of data protection related to the increased technology usage in conferences such as the use of unsecured apps and open Wi-Fi networks (BCD Meeting and Events- What's Trending Report, 2017) that are becoming increasingly popular. Thus safety concerns shift from solely personal security to both personal and cyber security (Meeting Professionals International, 2017).

Conference organisers, venues and destinations will be expected to increase security levels and measures such as physical security site inspections prior to the conference, security checks of delegates upon arrival, and increased uniformed security personnel (Palmer, 2018). This requires CVBs, accommodation venues, destinations and conference organisers to have plans in place to limit any risk resulting from instability (Palmer, 2017). For destinations, being considered a safe destination is a must, as safety and security are increasingly being considered a brand differentiator by conference delegates (Destination NEXT, 2017).

\section{LIMITATIONS}

A number of limitations of this study have also been identified. The questionnaire has been carried out within five conferences that were all based in Malta. This may create a bias in terms of participants' characteristics and perspectives. To mitigate such bias as much as possible, participants were required to confirm they have 
attended other international conferences prior to the one in Malta. This measure also helped mitigate another possible limitation related to lack of experience as a conference delegate. As some respondents filled in the questionnaire during the initial stages of the conference held in Malta, their delegate experience during that conference would not have been enough to base the responses on. Finally, the research focused only on the delegate's perspective. Other perspectives should be kept in consideration when discussing conference tourism, and thus it is suggested that future studies include such perspectives in their research.

\section{CONCLUSION}

The presentation and discussion of this study's findings should inform conference tourism stakeholders to make changes and updates in their strategies to attract conference delegates. While some areas might require less effort, success in other factors requires further planning and investment.

Contemporary delegates are less interested in attending a conference for its own sake and more interested in taking home an over-all positive conference experience. Delegates expect nothing less than a memorable experience, and this adds pressure on conference planners to find ways in which value can be added to the conference experience. One such way is by ensuring delegates take full benefit of their networking opportunities, keeping in mind networking expectations have increased. Planners need to provide the ideal networking environment and dedicated time slots for both formal and informal networking. This also puts pressure on conference and accommodation venues to plan for and be able to offer such dedicated space. Choice of increasingly flexible room set-ups is also required, in order to allow networking during sessions. 
This adds value to the conference experience, which may help in justifying all conference-related costs.

Technology is considered one of the main pillars of the conference industry and, with technology-related expectations constantly increasing, investment in this area is a must. Wi-Fi has become a necessity without which a conference cannot go ahead. Venues, destinations and any other interested locations should ensure they have full WiFi coverage and offer a fast-speed Wi-Fi. Mediocre speeds are no longer tolerated. Planning also has to consider power supply outlets. This might require infrastructural planning and changes at certain venues, but mitigation methods might exist. Providing portable charging devices to delegates may reduce the need for mobile charging ports, but laptops will still require available power outlets, which need to be planned for. Conference planners should also make more use of technology to improve the conference experience. There are various ways in which technology can be incorporated, such as by utilising apps for customer care, distributing agendas, instant communication with delegates, delivery of real-time presentations and marketing purposes.

Planners need to be sensitive to the limitations of delegates. One main limitation is time. Planners thus need to increasingly offer and promote flexible attendance, with options to buy a one-day or one-session ticket. Delegates increasingly expect to have control over what they participate in at a conference. Planners need to use systems whereby delegates have an option to pick the sessions they wish to attend, and choosing the slots they wish to use for networking, for break or for work. The possibility of offering concurrent sessions with different themes, and the same session repeated at intervals (possibly using VR) should be explored. This will allow delegates to construct their own agenda. 
A strong increase in concern over security and terrorism is also to be kept in consideration. Planners, venues and destinations have to ensure there is no compromise or half-measures on security, both physical and digital. These include security site inspections prior to the conference, security checks of delegates upon arrival, and increased uniformed security personnel. The support of local authorities might be required in some instances. A destination should invest heavily in promoting itself as a safe destination, and this should be prioritised even more if any neighbouring countries are not considered safe. In order to counter the spill-over effects in terms of negative image, the media has to be brought on board and investment in marketing the destination as safe needs to be stepped up a notch. Media is also required to educate potential delegates about the geographical area, and help make the distinction between the destination and (possibly less safe) neighbours.

Finally, increased education on the benefits of environmentally-friendly measures is required in order to help increase awareness and make such measures more attractive to delegates. In the current state, environmentally-friendly measures are not strong enough to attract conference tourism. The destinations' pull-factor is also on the decline compared to other motivators. Each destination should thus invest more in identifying their unique qualities and products and explore how these can be used to enhance the conference experience and marketed as a package. Factors such as culture have retained their attractiveness to delegates, and could thus help in enhancing the value of the conference package at a destination. Each destination stands to benefit from its unique characteristics but increased investment is required. Unless destinations invest in and promote their unique characteristics, they risk going into a downward price-war spiral, which would benefit no destination in the long term. 


\section{REFERENCES}

Abawi, K. (2008, January). Qualitative and quantitative research. World Health. Reproductive health research methodology training at the Ministry of Public Health Kabul, Afghanistan.

Al-Mahadin, S., \& Burns, P. (2006). Visitors, visions \& veils: the portrayal of the Arab American Express Meetings and Events (2018). 2018 Global meetings and events forecast. Retrieved from American Express Global Business Travel website: https://www.amexglobalbusinesstravel.com/content/uploads/2017/12/2018-GlobalMeetings-Forecast-US.pdf.

Andrews, F. (1984). Construct validity and error components of survey measures: a structural modelling approach. Public Opinion Quarterly, 48 (2), 409-442.

Avraham, E. (2015). Destination image repair during crisis: Attracting tourism during the Arab Spring uprisings. Tourism Management, 47, 224-232.

Baloglu, S., \& Love, C. (2005). Association meeting planners' perceptions and intentions for five major US convention cities: the structured and unstructured images. Tourism Management, 26(5), 743-752.

Baytok, A., Soybali, H.H. \& Emir, O. (2010). The Role of convention and visitors bureaus in marketing of destinations for convention tourism purposes: The case of Istanbul Convention and Visitors Bureau. Selçuk Üniversitesi Sosyal Bilimler Enstitüsü Dergisi.

BCD Meetings \& Events, 2017. What's Trending. Retrieved from BCD Meetings \&

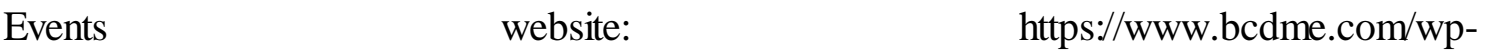
content/uploads/2017/11/092617_BCDME_TrendsReport.pdf

Bernini, C. (2009). Convention industry and destination clusters: Evidence from Italy. Tourism Management, 30 (6), 878-889. 
Campiranon, K., \& Arcodia, C. (2008). Market segmentation in time of crisis: A case study of the MICE sector in Thailand. Journal of Travel \& Tourism Marketing, 23(2-4), 151-161.

Chatzigeorgiou, C., Christou, E. \& Simeli, I. (2017). Delegate satisfaction from conference service quality and its impact on future behavioural intentions. Proceedings of the 5 th International Conference on Contemporary Marketing Issues ICCMI, June 21-23, 2017 Thessaloniki, Greece.

Chiu, L. K. \& Ananzeh, O. A. (2012). Evaluating the relationship between the role of promotional tools in MICE tourism and the formation of the touristic image of Jordan. Academica Turistica , 5 (1), 59-73.

Creswell, J.W. \& Creswell, J.D. (2017). Research design: Qualitative, quantitative, and mixed methods approaches. Thousand Oaks: Sage publications.

Cró, S. \& Martins, A.M. (2018). International association meetings: Importance of destination attributes. Journal of Vacation Marketing, 24(3), 218-233.

Crouch, G. \& Weber, K. (2002). Marketing of convention tourism. In Weber, K. and Chon, K.S. (Eds.), Convention Tourism: International Research and Industry Perspectives (pp. 57-78). Binghamton, N.Y.: Haworth; Northam: Roundhouse (distributor)

Crouch, G. I. \& Ritchie, J. R. (1997). Convention site selection research: A review, conceptual model, and propositional framework. Journal of Convention \& Exhibition Management, 1 (1), 49-69.

Crouch, G.I. \& Louviere, J.J. (2004). The determinants of convention site selection: A logistic choice model from experimental data. Journal of Travel Research, 43(2), 118130.

Davidson, R. \& Turner, A. (2017). Trends Watch Report 2017. Retrieved from Reeds Travel Exhibition

Ltd website: 
https:/www.ibtmworld.com/RXUK/RXUK_EIBTM/responsive/Documents/IBTM\%20

World_Trends\%20Watch\%20Report\%202017\%20A4\%2036pp\%20LOWRES.pdf?v=6 36474035207615127

Destinations International (2017). Destination Next - A strategic road map for the next generation of Global Destination Organizations. Retrieved from Destinations International website: https:/destinationsinternational.org/sites/default/master/files/Destinations_International _DestinationNEXT_2017_Futures_Study.pdf

Dioko ,L, \& Whitfield, J. (2015). Price competitiveness and government incentives for simulating the meetings industry. International Journal of Event and Festival Management, 6 (1), $39-53$.

Donaldson, R. (2013). Conference tourism: What do we know about the business tourist in South Africa? African Journal for Physical, Health Education, Recreation and Dance, 3, 24-38.

Dwyer, L., \& Kim, C. (2003). Destination competitiveness: Determinants and indicators. Current Issues in Tourism, 6(5), 369-414.

Fenich, G.G., Scott-Halsell, S., Ogbeide, G.C. \& Hashimoto, K. (2014). What the millennial generation from around the world prefers in their meetings, conventions, and events. Journal of Convention \& Event Tourism, 15 (3), 236- 241.

Filipović, M. G. (2012). A new prioritization method in the analytic hierarchy process applied on a case study of the convention site selection. JP Journal of Applied

Gantz, D. (2015). Sampling-The acid test. Retrieved from http:/www.samra.co.za/wp

German Convention Bureau (2013). Meetings and conventions 2030: A study of megatrends shaping our industry. Retrieved from Institute for Future Studies and 
https://www.izt.de/fileadmin/publikationen/GCB_zukunftsstudie_en_final_np.pdf

Grado, S. C., Strauss, C. H., \& Lord, B. E. (1997). Economic impacts of conferences and conventions. Journal of Convention \& Exhibition Management, 1, (1) 19-33.

Hahm, J.J., Breiter, D., Severt, K., Wang, Y. \& Fjelstul, J. (2016). The relationship between sense of community and satisfaction on future intentions to attend an association's annual meeting. Tourism Management, 52, 151-160.

Han, H. (2014). The norm activation model and theory-broadening: Individuals' decisionmaking on environmentally-responsible convention attendance. Journal of Environmental Psychology, 40, 462-471.

Hanly, P. (2011). Measuring the economic contribution of the international association conference market: An Irish case study. Tourism Management, 33 (6), 1574-1582.

Hayat, A., Severt, K., Breiter, D., Nusair, K. \& Okumus, F. (2014). Attributes influencing meeting planners' destination selection: A case of Orlando, Florida. Event Management, 18(2), 195-205.

Henderson, J.C. (2007). Hosting major meetings and accompanying protestors: Singapore 2006. Current Issues in Tourism, 10(6), 543-557.

Holloway, J.C., Humphreys, C., \& Davidson, R. (2009). The business of tourism. 8th ed. Canada: Pearson Education

Horváth, Z. (2011). The economic impacts of conference tourism in Siofol, the "capital" of Lake Balaton. Geojournal of Tourism \& Geosites ,1 (7), 75-86.

Hussain, K., Ragavan, N., Kumar, J. \& Navye Jr. R. (2014). Micro-impacts and benefits of business tourism in Malaysia: A case study of Kuala Lampur Convention Centre. AsiaPacific Journal of Innovation in Hospitality and Tourism, 3 (1), 107-130. 
International Association of Conference Centres (IACC) (2018). Meeting room of the $\begin{array}{llll}\text { future. } & \text { Retrieved } & \text { from }\end{array}$ http//www.meetingsmeanbusiness.com/sites/default/files/IACC\%20Meeting\%20Room \%20of\%20the\%20Future\%20Report\%202018.pdf

International Congress and Convention Association (ICCA) (2018). The international association meetings market 2017. ICCA statistics report- Public. Retrieved from ICCA website: https:/www.iccaworld.org/knowledge/benefit.cfm?benefitid=4036

Jago, L.K. \& Deery, M. (2005). Relationships and factors influencing convention decisionmaking. Journal of Convention \& Event Tourism, 7 (1), 23-41.

Jarumaneerat, T., Al-Sabbahy, H., \& Jones, P. (2007). Blackpool or Las Vegas? Which conference shall I go to this year? Hospitality Review, 9(1), 37-43.

Jung, S. \& Tanford, S. (2017). What contributes to convention attendee satisfaction and loyalty? A meta-analysis. Journal of Convention \& Event Tourism, 18 (2) 118-134.

Kim, S. S., Chon, K., \& Chung, K. Y. (2003). Convention industry in South Korea: An economic impact analysis. Tourism Management, 24(5), 533-541.

Kim, W. \& Malek, K. (2017). Understanding the relationship among motivation to attend, satisfaction, and loyalty of medical convention attendees. Journal of Convention \& Event Tourism, 18 (4), 282-300.

Krauss, S.E. (2005). Research paradigms and meaning making: A primer. The Qualitative Report, 10(4), 758-770.

Kronsik, J. A., \& Presser, S. (2009). Question and questionnaire design. Handbook of survey research.

Lee, C.K., Lee, M. \& Yoon, S.H. (2013). Estimating the economic impact of convention and exhibition businesses, using a regional input-output model: A case study of the 
Daejeon Convention Center in South Korea. Asia Pacific Journal of Tourism Research, 18(4), 330-353.

Lee, M. J. \& Back, K. J. (2007). Association members' meeting participation behaviors: Development of meeting participation model. Journal of Travel \& Tourism Marketing, 22(2), 15-33.

Lee, M.J. (2006). Analytical reflections on the economic impact assessment of conventions and special events. Journal of Convention \& Event Tourism, 8 (3), 71-85.

Lee, S. \& Fenich, G. G. (2016). Perceived fairness of room blocks in the meetings, incentives, convention, and exhibition industry. Journal of Convention \& Event Tourism, 17(2),159-171.

Lee, T. H. \& Park, J. Y. (2002). Study on the degree of importance of convention cervice factors: Focusing on the differences in perception between convention planners and participants. Journal of Convention \& Exhibition Management, 3 (4), 69-85.

Loker, E. L. and Perdue, R. R. (1992). A benefit-based segmentation of a non-resident summer travel market. Journal of Travel Research , 31(1), 30-35.

Mair, J. \& Frew, E. (2016). Academic conferences: A female duo-ethnography. Current Issues in Tourism, 1-21.

Mair, J. \& Thompson, K. (2009). The UK association conference attendance decisionmaking process. Tourism Management. 30(3), 400-409.

Mair, J. (2013). Conferences and conventions: A research perspective. London: Routledge.

Mair, J., Lockstone-Binney, L. \& Whitelaw, P.A. (2018). The motives and barriers of association conference attendance: Evidence from an Australasian tourism and hospitality academic conference. Journal of Hospitality and Tourism Management, 34,58-65. 
Marques, J. \& Santos, N. (2016). Developing business tourism beyond major urban centres: the perspectives of local stakeholders. Tourism and Hospitality Management, 22(1), 1-15.

Mason, M. C., \& Nassivera, F. (2013). A conceptualization of the relationships between quality, satisfaction, behavioural intention, and awareness of a festival. Journal of Hospitality Marketing \&Management, 22 (2), 162-18

Mathematics, 3 (2), 63-80.

Meeting Professionals International (2017). Meetings Outlook. Retrieved from Meeting Professionals International website: https:/www.mpiweb.org/docs/defaultsource/meetings-outlook/meetings-outlook-fall-2017.pdf

Ngamsom, B. \& Beck, J. (2000). A pilot study of motivations, inhibitors, and facilitators of association members in attending international conferences. Journal of Convention \& Exhibition Management, 2 (2-3), 97- 111.

Oates, G. (2017, January). 3 trends that will disrupt the meetings and events industry in 2017. Skift Inc. Retrieved from https:/skift.com/2017/01/04/3-trends-that-will-disruptthe-meetings-and-events-industry-in-2017/

Oppermann, M., \& Chon, K. S. (1997). Convention participation decision-making process. Annals of Tourism Research, 24(1), 178-191.

Palmer, A. (2017, December). Industry experts predict 2018 meeting trends. Successful Meetings. Retrieved from: http:/www.successfulmeetings.com/Strategy/MeetingStrategies/2018-Meeting-Trends-Security-Diversity-Experiential/?p=2/

Palmer, A. (2018, January). Meeting trends for 2018. Successful Meetings. Retrieved from: http://www.successfulmeetings.com/Strategy/Meeting-Strategies/Meetings-Trends-for2018-Security-Experiential-Events/ 
Pittman, J. \& McLaughlin, B. (2012). Professional conferences, social capital and tourism: Is the alliance in jeopardy?. Tourism and Hospitality, 1(2), 109.

Ramirez, D., Laing, J., \& Mair, J. (2013). Exploring intentions to attend a convention: A gender perspective. Event Management, 17(2), 165-178.

Ranacher, L. \& Pröbstl-Haider, U. (2014). Green meetings: ecocertification of sustainable events in conference and business tourism. Sustainable Tourism VI, 187, 121.

Rittichainuwat, B. N., Beck, J. A. and Lalopa, J. (2001). Understanding motivations, inhibitors, and facilitators of association members in attending international conferences. Journal of Convention \& Exhibition Management, 3 (3), 45-62.

Rogers, T. (2013). Conferences and Conventions $3^{\text {rd }}$ edition: A global industry. Oxon: Butterwort- Heinemann.

Rogers, T. and Davidson, R. (2015). Marketing destinations and venues for conferences, conventions and business events. London: Routledge.

Ryan, C., Crotts, J. \& Litvin, S. (2008). Convention center management-Influencing the attendee experience: The case of Charleston Convention Center. Tourism Analysis, 13(2), 157-169.

Saris, W. E., \& Gallhofer, I. N. (2014). Design, evaluation, and analysis of questionnaires for survey research. John Wiley \& Sons.

Severt, D., Wang, Y., Chen, P. J. \& Breiter, D. (2007). Examining the motivation, perceived performance, and behavioral intentions of convention attendees: Evidence from a regional conference. Tourism Management, 28(2), 399-408.

Shapiro, M. J. (2011, October). Amex M\&E forecast: Meetings industry to continue steady growth. Meetings and Conventions. Retrieved from http://www.meetingsconventions.com/news/breaking-news/amex-m-and-e-forecast-meetings-industry-2019/ 
Skinner, H. (2017). Business tourists' perceptions of nation brands and capital city brands: a comparison between Dublin/Republic of Ireland, and Cardiff/Wales. Journal of Marketing Management, 33(9-10), 817-834.

Solly, I. (2012). International comparative report. MICE tourism in Malta and Cyprus. Case Studies in International Tourism.

Sukamolson, S. (2007). Fundamentals of quantitative research. Language Institute, Chulalongkorn University. Retrieved from: http//www.culi.chula.ac.th/Research/eJournal/bod/Suphat\%20Sukamolson.pdf

Superio, D.L. \& Anderson, K.L. (2016, October). Factors affecting the attendance of IAMSLIC members at IAMSLIC annual conference. Proceedings of the Traditional Knowledge and Modern Information Practice: 42nd IAMSLIC Annual Conference, Mexico.

Tabachnick, B. G. and Fidell, L. S. (1996). Using multivariate statistics. 3rd edition. New York: HarperCollins.

Tanford, S. \& Montgomery, R. (2015). Developing loyalty programs for convention attendees: An exploratory study. International Journal of Hospitality \& Tourism Administration, 16(1), 57-77.

Tanford, S., Montgomery, R. \& Nelson, K.B. (2012). Attendance, satisfaction, and loyalty for conventions. Journal of Convention \& Event Tourism, 23 (4), 290-318.

Taylor, P. A. (2006). Getting them to forgive and forget: cognitive based marketing responses to terrorist acts. International Journal of Tourism Research, 8,171-183.

Tretyakevich, N. \& Maggi, R. (2011). Not just for business: some evidence on leisure motivations of conference attendees. Current Issues in Tourism, 15 (4), 391-395.

Validity Research (2015). On-location Intercept. Retrieved from http://valid ityresearch.com/quantitative/on-location-intercept/ 
Wan, Y.K.P (2011). Assessing the strengths and weaknesses of Macao as an attractive meeting and convention destination: Perspectives of key informants. Journal of Convention \& Event Tourism, 12 (2), 129-151.

White, P.C., Jennings, N.V., Renwick, A.R. \& Barker, N.H.L. (2005). Questionnaires in ecology: A review of past use and recommendations for bet practice. Journal of Applied Ecology, 42 (3), 421-430.

Whitfield, J.E. (2009). Why and how UK visitor attractions diversify their product to offer conference and event facilities. Journal of Convention \& Event Tourism, 10 (1), 72-88.

world in tourism advertising. In R. Dahar (Ed.), Tourism in the Middle East: Continuity, change and transformation (pp. 137- 160). Channel View Publications.

Yoo, J.J.E. \& Chon, K. (2008). Factors affecting convention participation decisionmaking: Developing a measurement scale. Journal of Travel Research, 47(1), 113-122.

Yoo, J.J.E. \& Zhao, X. (2010). Revisiting determinants of convention participation decision making. Journal of Travel \& Tourism Marketing, 27(2), 179-192.

Zhang, H., Leung, V. \& Qu, H. (2007). A refined model of factors affecting convention participation decision-making. Tourism Management, 28 (4), 1123-1127. 